\title{
Development of Treatment Unit for the Treatment of Municipal Wastewater of Rajshahi City
}

\author{
Md Niamul Bari*, Md Kamrul Islam and Md Rashedur Rahman \\ Department of Civil Engineering, Rajshahi University of Engineering \& Technology, Bangladesh
}

*Corresponding author: Md Niamul Bari, Department of Civil Engineering, Rajshahi University of Engineering \& Technology, Bangladesh

\begin{abstract}
This research paper deals with the development of filter unit to treat the wastewater collected from municipal drain near City Hat area of Rajshahi City. The horizontal flow filtration process was considered for treatment of wastewater. Whole filtering system contains three to four layers where sand layer acts as the main filtering media. Besides, various sizes of coarse aggregates which works as filter media and base materials. The thickness of sand layer was used $600 \mathrm{~mm}$ while other coarse aggregate layers were about $150 \mathrm{~mm}$. There were three different sizes coarse aggregate. Top most layer contained the coarse aggregate of size varying from $3 \mathrm{~mm}$ to $6 \mathrm{~mm}$. The intermediate layer contained the coarse aggregate of size varying from $20 \mathrm{~mm}$ to $40 \mathrm{~mm}$ and the last layer contained the large coarse aggregate of size varying from $40 \mathrm{~mm}$ to $65 \mathrm{~mm}$.The main purpose of this study was to reduce the pollutant concentration.
\end{abstract}

Keywords: Municipal water; Treatment; pH; Turbidity; Alkalinity; Organic content; Filter; Rajshahi

\section{Introduction}

Wastewater is defined as the water which is negatively impacted by public use. It can be formed by many operations such as domestic, commercial or agricultural operations etc. Such kind of water includes many pollutants above their permeable limits. Wastewater depends on its source, it may be household or it can be generated from industry. Households produce such kind of wastewater by daily activity. It generates from dishwashers, flush toilets, sinks, bath tubs etc. In case of urban communities, the wastewater produced by households with sewers is called municipal wastewater or sewage. Wastewater is comparatively less produced in households that use dry toilets than using flush toilets. The transportation of wastewater either be done by municipal sewer or combined sewer. After completing the treatment of wastewater in a treatment plant, the treated effluent is released to a receiving water body. Then this water is ready for use.

Rajshahi stands by the river of Padma and about 43lpcd municipal wastewater is discharged into the river without any considerable treatment [1]. As a result, water of this river is populated day by day. Besides, researchers and scientists said that the Baranai River flowing through the northern part of city is heavily polluted and contaminated with wastes and chemicals.
The surrounding crop fields are also being polluted every day due to hazardous waste water. This water is being used by farmers for irrigation purposes. Fisher men are catching fishes every day from these rivers, so every is hazardous and harmful to human health and environment.

Many people from various parts of the country are gathering to Rajshahi city for study, seeking jobs and working in the city's cottage and small industries. Meanwhile, the multistoried buildings, clinics, hospitals, diagnostic centers, small industrial units are also increasing constantly with an increasing number in the city. From these sources also from Rajshahi Medical College Hospital a large amount of toxic wastes is being disposed to nearby rivers through drains of RCC (Rajshahi City Corporation). Moreover, toxic effluent without any treatment from the BSCIC industrial units and textile industries are also pouring through the city drains into these rivers. This wastewater which is called polluted water bears many impurities which are harmful for public health and environment. The impurities present in wastewater refractory organics, biodegradable organics, are suspended solids nutrients, heavy metals, pathogens dissolved organic solids. These impurities cause communicable diseases, eutrophication, toxicity, anaerobic conditions in aquatic environment [2]. So, in a word, this 
wastewater is harmful for human health and environment. The untreated wastewater can cause severe damage on public health and nature. Even if, it can break down the ecosystem. Treatment of municipal wastewater is difficult due to extremely complex and variable composition. As a result, the lack of fresh water is increasing but with the increment of population, the demand of fresh water is increasing day by day. With increasing need of potable water there is no enough drinking water to supply. Primary treatment followed by secondary biological treatment by activated sludge of wastewater is ineffective in decolorization and toxicity removal, for this reason, tertiary treatment is needed for advanced oxidation process. But the techniques for this treatment are more costly and intensive. So, this advanced oxidation process means tertiary treatment is not always possible to apply. Sometimes, Bacterial biomass was used to treat municipal wastewater but in this case, there is possibility of forming byproducts which are more harmful to environment than existing compounds. Intrusion of contaminated water into ground water and fresh water bodies pose a serious threat to communities using these sources for water use [3].

According to the above information, every day a huge number of polluted water is discharging to the water bodies which is very harmful for public health and environment. If it continues, it will be very dangerous, and our existence will be at risk. So, it is important to treat this municipal wastewater to protect ourselves and our environment and this treatment system should be cheap and easy to operate. It will be best if it is possible to make this system using local materials having low market value. In this case, slow sand filtration process is more acceptable which is very cheap and easily to use and prepare.

Slow sand filter may be a method that is employed in water purification for treating raw water to supply a potable product. It can be 1-2 meters deep and its shape may be rectangular or cylindrical. According to the flow rate of filter, the length and breadth of filter is determined, which typically has a loading rate of 0.2 to 0.4 liters per hour (or cubic meters per square meter per hour) [4-7].

Table 1: Maximum Permissible Limits (MPL) for wastewater discharging into natural receiving bodies and for irrigation (IS: 2490, Part-I-1981).

\begin{tabular}{|c|c|c|c|}
\hline Parameters & Unit & $\begin{array}{c}\text { MPL for } \\
\text { irrigation }\end{array}$ & $\begin{array}{c}\text { MPL for } \\
\text { natural body }\end{array}$ \\
\hline $\mathrm{Ph}$ & - & $5.5-9.0$ & $5.5-9.0$ \\
\hline Conductivity & micromhos/cm & 2250 & 2250 \\
\hline Turbidity & $\mathrm{NTU}$ & 35 & 35 \\
\hline Alkalinity & $\mathrm{mg} / \mathrm{L}$ & 600 & 600 \\
\hline Acidity & $\mathrm{mg} / \mathrm{L}$ & 200 & 200 \\
\hline $\begin{array}{c}\text { Total Suspended } \\
\text { Solid (TSS) }\end{array}$ & $\mathrm{mg} / \mathrm{L}$ & 100 & 200 \\
\hline $\begin{array}{c}\text { Total Dissolved } \\
\text { Solid (TDS) }\end{array}$ & $\mathrm{mg} / \mathrm{L}$ & 2000 & 2000 \\
\hline $\begin{array}{c}\text { Total Organic } \\
\text { Content (TOC) }\end{array}$ & $\mathrm{mg} / \mathrm{L}$ & 250 & 200 \\
\hline
\end{tabular}

In this study, an attempt has been made to check the qualities of wastewater and tried to treat them with slow sand filtration process to make them suitable for irrigation purposes, even freely discharge in Padma river without any hazardous elements. Maximum permissible limits for wastewater discharging into natural receiving water bodies and for irrigation are shown in Table 1.

\section{Background}

The first documented use of sand filters to purify the water supply dates to 1804 , when the owner of a bleachery in Paisley, Scotland, John Gibb, installed an experimental filter, selling his unwanted surplus to the public. This method was refined in the following two decades by engineers working for private water companies, and it culminated in the first treated public water supply in the world, installed by engineer James Simpson for the Chelsea Waterworks Company in London in 1829. This installation provided filtered water for every resident of the area, and the network design was widely copied throughout the United Kingdom in the ensuing decades.

The practice of water treatment soon became mainstream, and the virtues of the system were made starkly apparent after the investigations of the physician John Snow during the 1854 Broad Street cholera outbreak. Snow was skeptical of the then-dominant miasma theory that stated that diseases were caused by noxious "bad airs". Although the germ theory of disease had not yet been developed, Snow's observations led him to discount the prevailing theory. His 1855 essay On the Mode of Communication of Cholera conclusively demonstrated the role of the water supply in spreading the cholera epidemic in Soho, with the use of a dot distribution map and statistical proof to illustrate the connection between the quality of the water source and cholera cases. His data convinced the local council to disable the water pump, which promptly ended the outbreak [8-10].

The Metropolis Water Act introduced the regulation of the water supply companies in London, including minimum standards of water quality for the first time. The Act "made provision for securing the supply to the Metropolis of pure and wholesome water", and required that all water be "effectually filtered" from 31 December 1855.This was followed up with legislation for the mandatory inspection of water quality, including comprehensive chemical analyses, in 1858. This legislation set a worldwide precedent for similar state public health interventions across Europe. The Metropolitan Commission of Sewers was formed at the same time, water filtration was adopted throughout the country, and new water intakes on the Thames were established above Toddington Lock.

Water treatment came to the United States in 1872 when Poughkeepsie, NY opened the first slow sand filtration plant, dramatically reducing instances of cholera and typhoid fever which had been seriously impacting the local community. Poughkeepsie's design criteria were used throughout the country as a model for other municipalities. Poughkeepsie's original treatment facility operated continuously for 87 years before being replaced in 1959 [11-14]. 


\section{Design and Construction}

A treatment unit is developed in this study which is like as slow sand filter. The developed treatment unit is horizontal filter unit means the slope of the filter unit is very small. So, water is passed through the filter media at a slow rate. This filter unit is developed using available local materials.

In this study, the filter unit is developed using the following materials -

1. UPVC pipe. This is used as filter unit's body. The length of the pipe was $6 \mathrm{ft}$ and diameter 6 inch.

2. Fine sand. Main filter media of this filter unit.

3. Small size coarse aggregate used as filter media.

4. Medium size coarse aggregate used as filter media.

5. Large size coarse aggregate used as filter media.

The developed filter unit is divided into two steps based on the number of layers. In the first step, three layers are used in the filter unit and in the second step an additional layer is added to the filter unit. In first step, following three layers are used-
1. Fine sand layer. Size of the fine sand varies from $0.2 \mathrm{~mm}$ to $0.3 \mathrm{~mm}$. The length of this layer is $600 \mathrm{~mm}$.

2. Medium size coarse aggregate. Size of the medium size coarse aggregate varies from $20 \mathrm{~mm}$ to $40 \mathrm{~mm}$ and the length of this layer is $150 \mathrm{~mm}$.

3. Large size coarse aggregate. Size of the large size coarse aggregate varies from $40 \mathrm{~mm}$ to $65 \mathrm{~mm}$ and the length of this layer is $150 \mathrm{~mm}$

In case of second step, another layer is added, and that layer is-

1. Small size coarse aggregate.

Size of the small size coarse aggregate varies from $3 \mathrm{~mm}$ to $6 \mathrm{~mm}$ and the length of this layer is $150 \mathrm{~mm}$.

In front of the filter unit there is an empty space just after the inlet. Here, wastewater is poured from collected container. And the water can pass through the filter media. The slope of this filter unit is 1 in 125 which is within the standard value [4]. The treated water is then collected in another container at the outlet of the filter unit (Figure 1 \& 2).

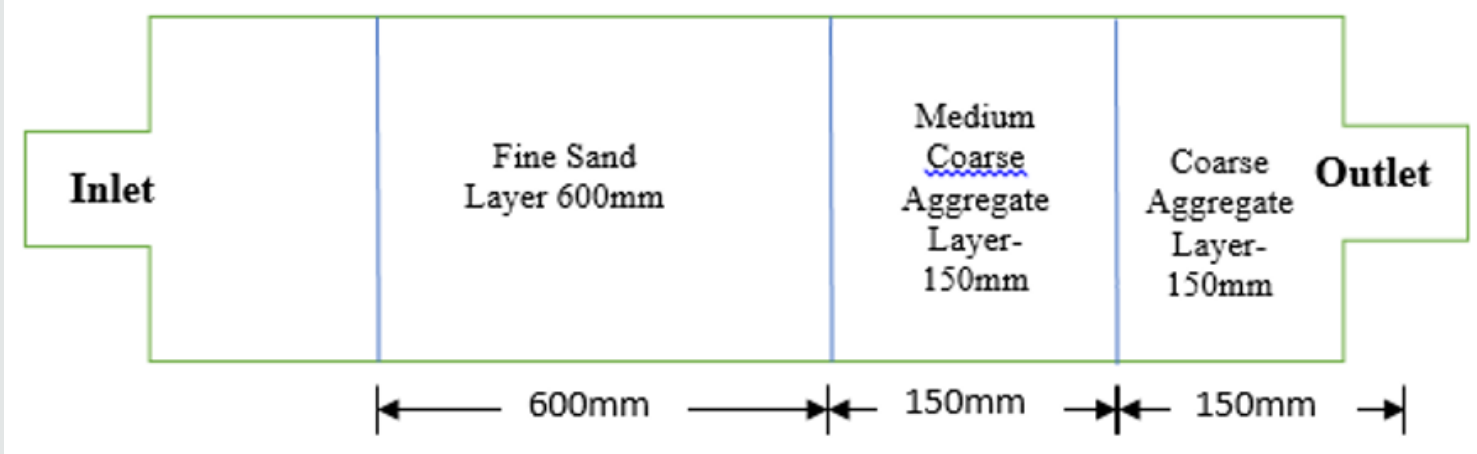

Figure 1: Plan of filter with three layers.

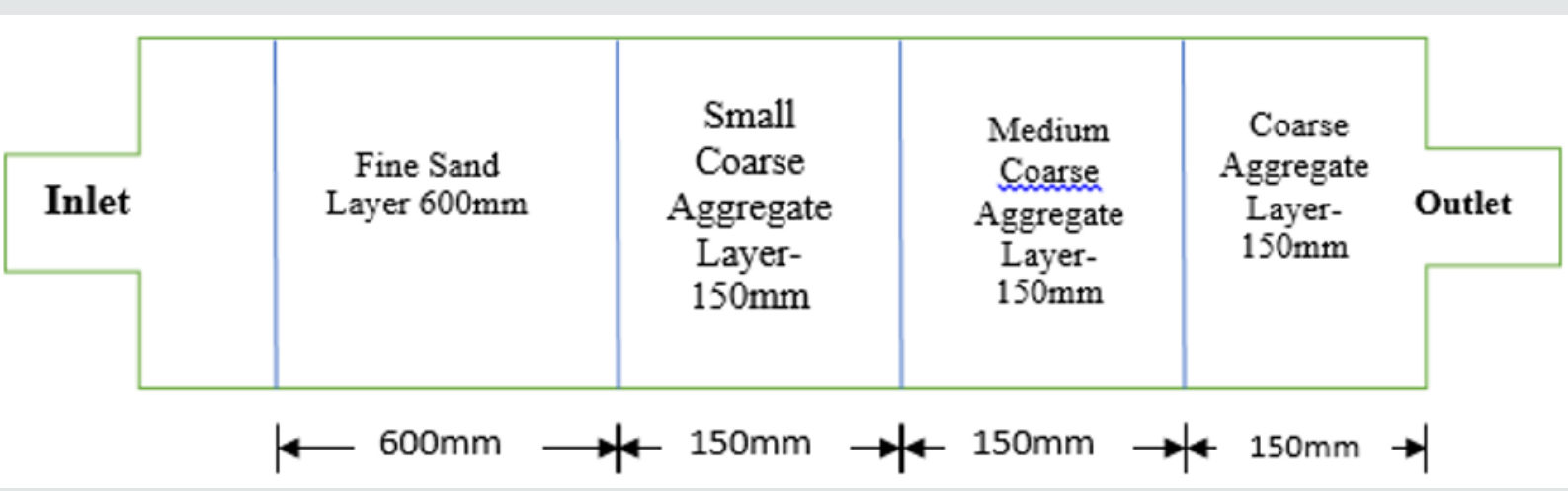

Figure 2: Plan of filter with four layers.

\section{Methodology}

The characteristics of wastewater sample collected from City Hat need to be determined by various tests like determination of $\mathrm{pH}$, conductivity, total solid, suspended solid, dissolved solid, alkalinity, acidity, organic content etc. The allowable limit of these properties of water, to use in irrigation channel, needs to be compared with the wastewater samples properties. The characteristics properties which are beyond the allowable limit should be reduced if the water is to use in irrigation channel. Wastewater treatment process like coagulation reduces these properties and can make the water fit for using it in irrigation channel. 
Wastewater sample was collected from primary drain located at City hat in Rajshahi City Corporation area. Representative wastewater sample was collected in PET bottle in sufficient quantity by following standard procedure. The sample was brought as early as possible to the laboratory and kept in chiller below $4 \mathrm{oC}$ temperature to protect from the physical, chemical and biological changes. The experiment was done with great care and timely. There are three characteristics of municipal wastewater, such as physical characteristics, chemical characteristics and biological characteristics. Considering the intended treatment of municipal wastewater, the physical and chemical characteristics were determined based on turbidity, TDS, TSS, TS, pH, conductivity, acidity, alkalinity and organic content.

\section{Results and Discussion}

All tests were conducted in Public Health Laboratory, Rajshahi University of Engineering and Technology, Rajshahi. The results, obtained from laboratory test are shown in this chapter. Firstly, the quantification of the wastewater was done, then, untreated wastewater was characterized and compared with the standard values. In the second case, wastewater was treated with three layers of filter and all parameters were compared with the maximum permeability. At the final stage, wastewater was treated with four layers of filter and all parameters of the wastewater were below their permeable limits.

\section{Quantification of waste water}

For the determination of quantification of municipal wastewater of Rajshahi City, at first a certain length of flow had been taken. Then the width of the flow channel was taken. Finally, the height of the flow channel was also taken. Using stop watch required time was recorded. The cross-sectional area of the certain portion of the flow channel was measured from width and height. Then velocity was calculated. So, the quantification was obtained using the equation Discharge, $\mathrm{Q}=\mathrm{AV}$ where, $\mathrm{A}=$ cross sectional area and $\mathrm{V}=$ velocity. $\mathrm{Q}=25.98 \times 10^{6}\left(\mathrm{~m}^{3} / \mathrm{yr}\right.$.

\section{Characterization of untreated waste water}

The sample of untreated wastewater which was collected from City Hat in Rajshahi City was analyzed by different physical and chemical parameter test. At first $\mathrm{pH}$ and conductivity test was performed for various samples and result obtained was compared to allowable limits, $\mathrm{pH}$ and conductivity was within tolerable limits. Then Turbidity machine was calibrated, and reading was taken. Turbidity of untreated sample was very high and crossed maximum permissible value. After that alkalinity and acidity was measured by titration, although the value was high, but it was under permissible limit. Then total solid, total suspended solid and total dissolved solid test were performed, the value obtained was very high and crossed permissible limit. Finally, organic content test was performed, and results obtained was within permissible limit. Results obtained are shown as follows

\section{Determination of $\mathbf{p H}$}

Table $2 \mathrm{pH}$ values of municipal wastewater of Rajshahi City. The value of $\mathrm{pH}$ found from the sample is within permissible limit as the tolerable limit is between 5.5 and 9.0. So, the $\mathrm{pH}$ value found by experiment shows that the water possesses moderate $\mathrm{pH}$ and it has no significant effect in pollution of wastewater (Figure 3).

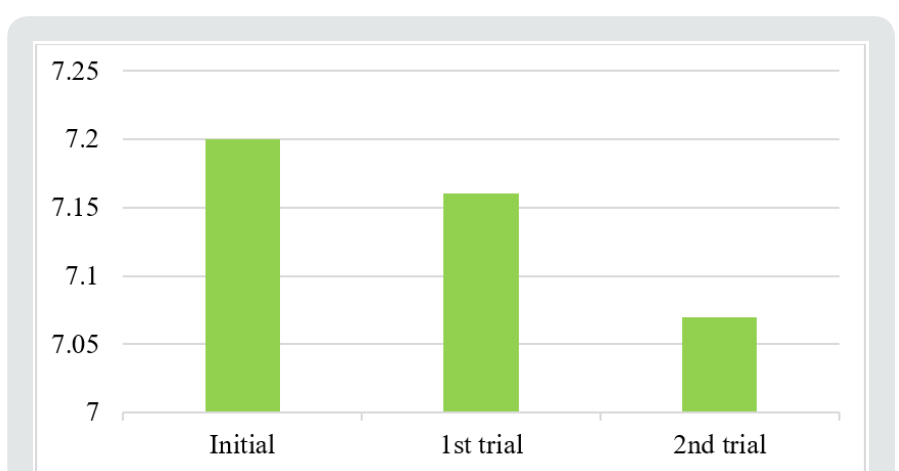

Figure 3: $\mathrm{pH}$ values of municipal wastewater of Rajshahi City.

Table 2: $\mathrm{pH}$ values of municipal wastewater of Rajshahi City.

\begin{tabular}{|c|c|c|c|}
\hline Location & Initial $\mathbf{p H}$ & $\mathbf{1}^{\text {st }}$ trial $\mathbf{p H}$ & $\mathbf{2}^{\text {nd }}$ trial $\mathbf{p H}$ \\
\hline City Hat & 7.2 & 7.16 & 7.07 \\
\hline
\end{tabular}

\section{Determination of conductivity}

The maximum permissible limit of conductivity is $2250 \mu$ mhoes/ $\mathrm{cm}$. The results are shown in Figure 4.

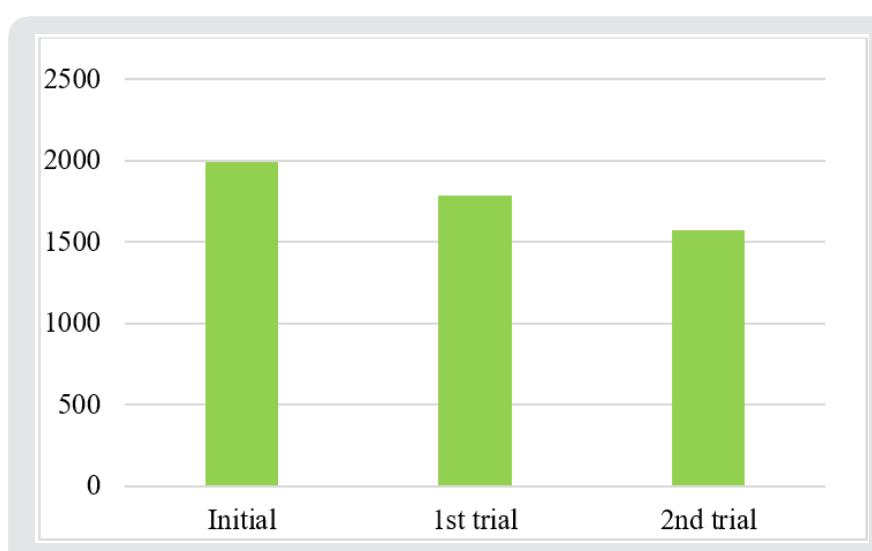

Figure 4: conductivity values of municipal wastewater of Rajshahi City.

The value of conductivity found from the sample is within permissible limit as the tolerable limit is $2250 \mathrm{micromhos} / \mathrm{cm}$. So, the value found by experiment shows that the water possesses tolerable and it has no significant effect in pollution of wastewater (Table 3).

Table 3: conductivity values of municipal wastewater of Rajshahi City.

\begin{tabular}{|c|c|c|c|c|c|}
\hline Location & $\begin{array}{c}\text { Initial } \\
\text { Conduct } \\
\text { ivity } \\
(\mu \mathrm{mhoes} / \\
\mathbf{c m})\end{array}$ & $\begin{array}{c}\mathbf{1}^{\text {st }} \text { trial } \\
\text { Conduct } \\
\text { ivity } \\
(\mu \mathrm{mhoes} / \\
\mathbf{c m})\end{array}$ & $\begin{array}{c}\text { \% of } \\
\text { Removal } \\
\text { in } \mathbf{1}^{\text {st }} \\
\text { trial }\end{array}$ & $\begin{array}{c}\mathbf{2}^{\text {nd }} \text { trial } \\
\text { Conduct } \\
\text { ivity } \\
(\mu \mathrm{mhoes} / \\
\mathbf{c m})\end{array}$ & $\begin{array}{c}\text { \% of } \\
\text { Removal } \\
\text { in 2 } \\
\text { trial }^{\text {trial }}\end{array}$ \\
\hline City Hat & 1990.5 & 1785 & 10.32 & 1573 & 20.97 \\
\hline
\end{tabular}




\section{Determination of turbidity}

The maximum allowable limit for turbidity is 35 NTU. The results are shown in Figure 5. The value of turbidity found from the sample has crossed permissible limit as the tolerable limit is 35NTU and the sample possesses turbidity value beyond the tolerable limit. So, the value found by experiment shows that the wastewater is very highly turbid, and it has significant effect in pollution of wastewater (Table 4).

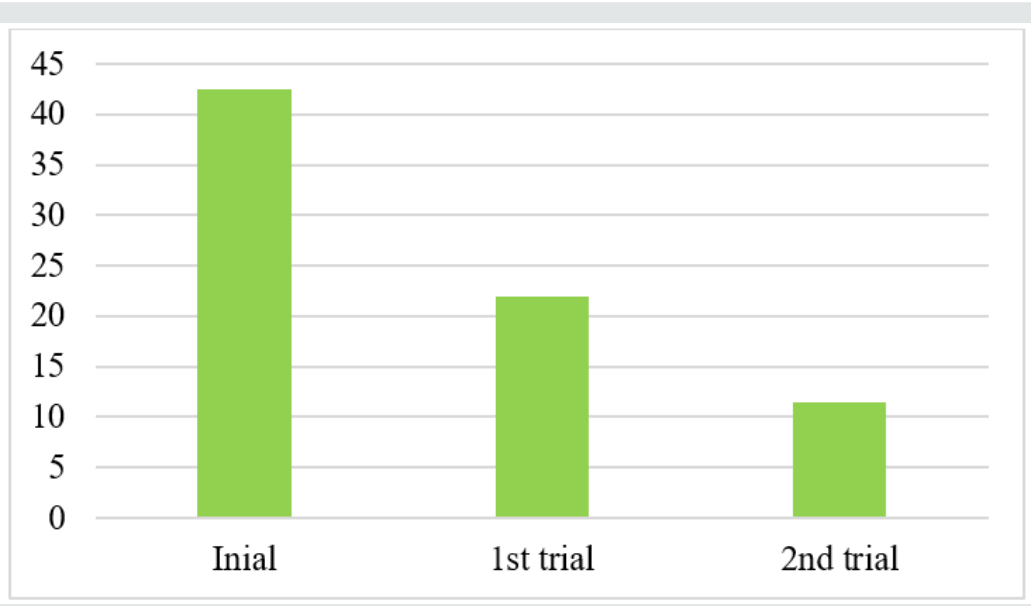

Figure 5: Turbidity values of municipal wastewater of Rajshahi City.

Table 4: Conductivity values of municipal wastewater of Rajshahi City.

\begin{tabular}{|c|c|c|c|c|c|}
\hline Location & $\begin{array}{c}\text { Initial Turbidity } \\
\text { (NTU) }\end{array}$ & $\begin{array}{c}\mathbf{1}^{\text {st }} \text { trial Turbidity } \\
\text { (NTU) }\end{array}$ & Removal (\%) & $\begin{array}{c}\mathbf{2}^{\text {nd }} \text { trial Turbidity } \\
\text { (NTU) }\end{array}$ & Removal (\%) \\
\hline City Hat & 42.5 & 22 & 48.24 & 11.5 & 72.94 \\
\hline
\end{tabular}

\section{Determination of alkalinity}

The Maximum allowable limit $600 \mathrm{mg} / \mathrm{L}$. The results are shown in Figure 6. The value of alkalinity found from the sample is within permissible limit as the tolerable limit is $600 \mathrm{mg} / \mathrm{L}$ and the sample

possesses conductivity value within the tolerable limit. So, the value found by experiment shows that the water possesses alkalinity that is permissible, and it has very less effect in pollution of wastewater (Table 5).

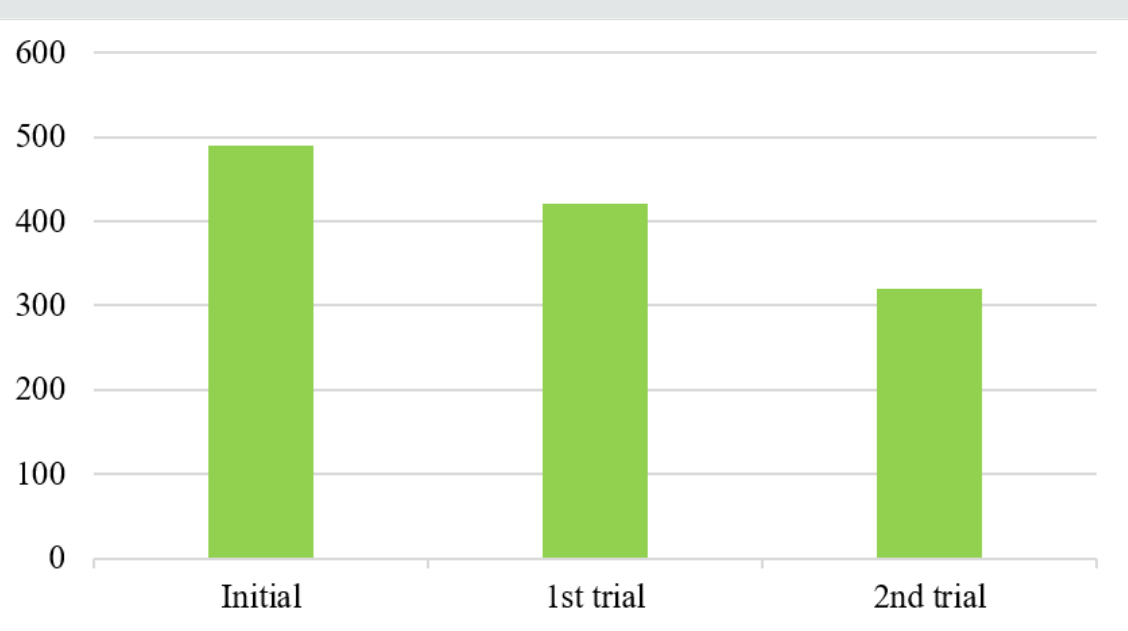

Figure 6: Alkalinity values of municipal wastewater of Rajshahi City.

Table 5: Alkalinity values of municipal wastewater of Rajshahi City.

\begin{tabular}{|c|c|c|c|c|c|}
\hline Location & $\begin{array}{l}\text { Initial Alkalinity } \\
\text { (ppm) }\end{array}$ & $\begin{array}{l}1^{\text {st }} \text { trial Alkalinity } \\
\text { (ppm) }\end{array}$ & $\begin{array}{c}\% \text { of removal in } 1^{\text {st }} \\
\text { trial }\end{array}$ & $\begin{array}{l}2^{\text {nd }} \text { trial Alkalinity } \\
(\mathrm{ppm})\end{array}$ & $\begin{array}{c}\% \text { of removal in } 2^{\text {nd }} \\
\text { trial }\end{array}$ \\
\hline City Hat & 490 & 420 & 14.29 & 320 & 34.69 \\
\hline
\end{tabular}


Determination of total solid, total suspended solid and total dissolved solid

Total solid is the material residue left in the vessel after evaporation of the sample. Total suspended solids (TSS) give a measure of the turbidity of the water. Total dissolved solid (TDS) is nothing but the dissolved inorganic impurities present in the sample. The maximum permissible limit of Total Suspended Solid (TSS) is $100 \mathrm{mg} / \mathrm{L}$ for direct discharge into natural water bodies and $200 \mathrm{mg} / \mathrm{L}$ for use in irrigation. The maximum allowable limit of Total Dissolved Solid (TDS) is $2000 \mathrm{mg} / \mathrm{L}$. The results are shown in Figure 7-10 (Table 6 \& 7).

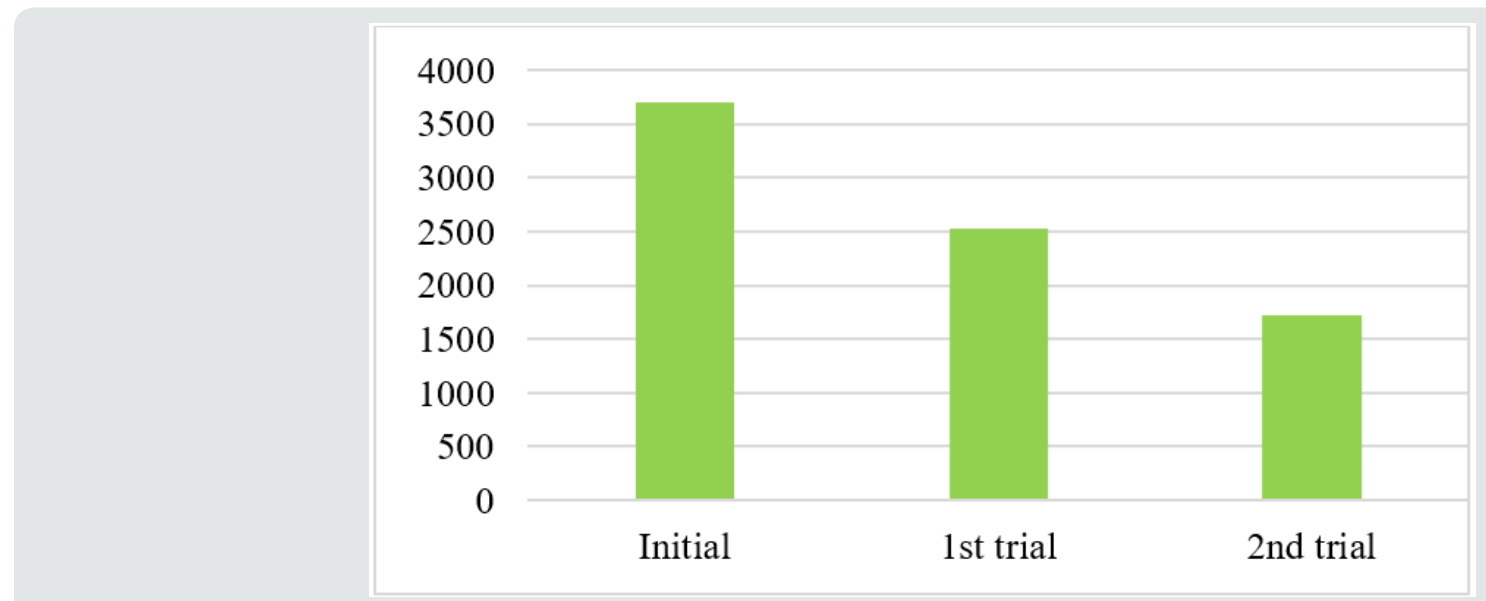

Figure 7: Values of Total Solid of municipal wastewater of Rajshahi City.

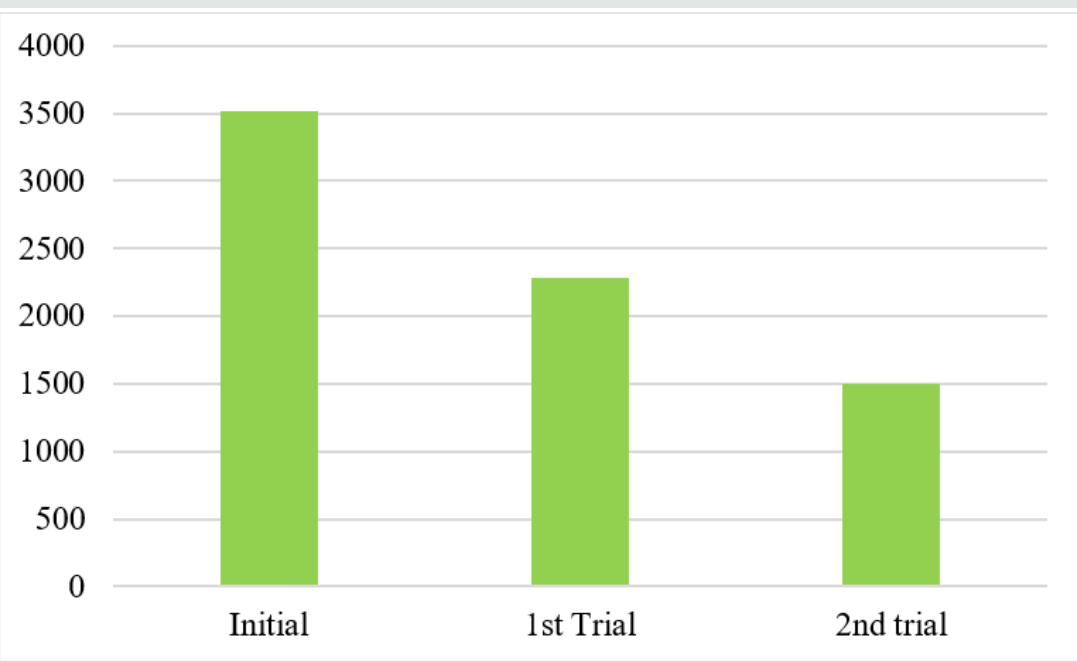

Figure 8: Values of Total Dissolved Solid (TDS) of municipal wastewater of Rajshahi City.

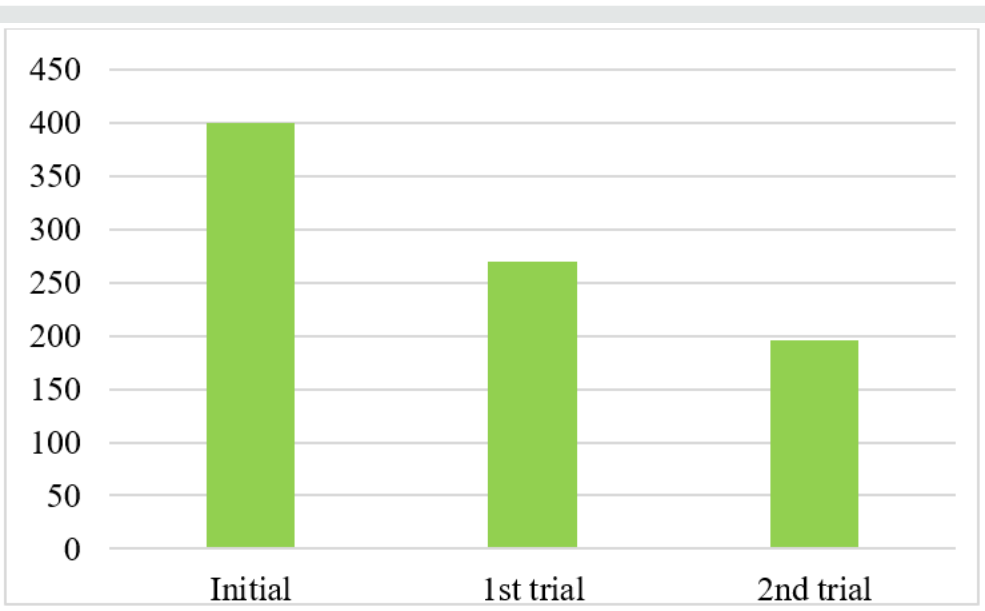

Figure 9: Values of Total Suspended Solid (TSS) of municipal wastewater of Rajshahi City. 


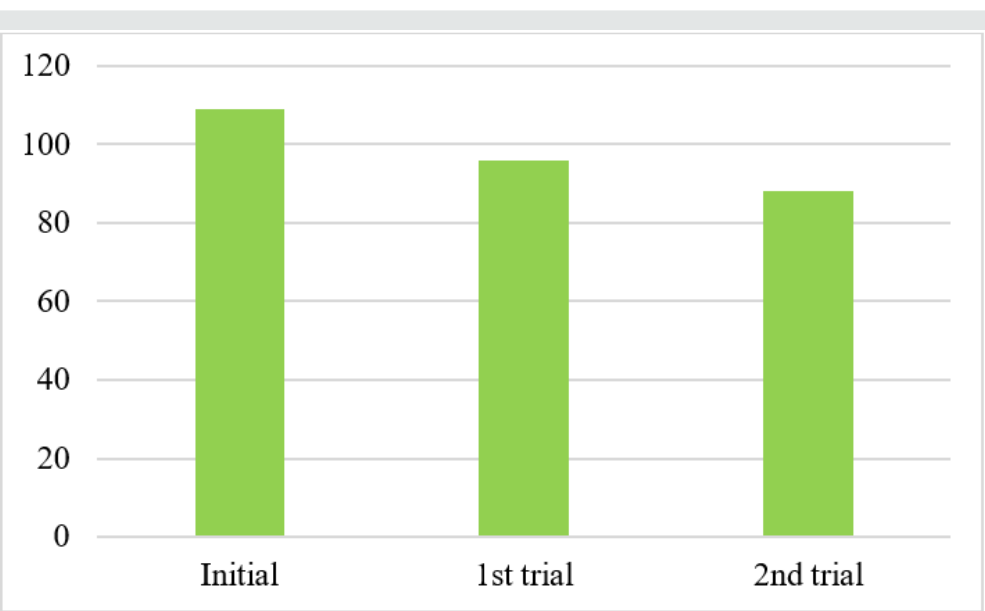

Figure 10: Total organic content values of municipal wastewater of Rajshahi City.

Table 6: Values of Total Solid (TS) of municipal wastewater of Rajshahi City.

\begin{tabular}{|c|c|c|c|c|c|}
\hline Location & Initial TS (mg/l) & $\mathbf{1}^{\text {st }}$ Trial TS (mg/l) & Removal (\%) & 2 $^{\text {nd }}$ Trial TS(mg/l) & Removal (\%) \\
\hline City Hat & 3700 & 2520 & 31.89 & 1720 & 53.51 \\
\hline
\end{tabular}

Table 7: Values of Total Dissolved Solid (TS) of municipal wastewater.

\begin{tabular}{|c|c|c|c|c|c|}
\hline Location & Initial TDS (mg/l) & $\mathbf{1}^{\text {st }}$ Trial TDS (mg/l) & Removal (\%) & 2 $^{\text {nd }}$ Trial TDS(mg/l) & Removal (\%) \\
\hline City Hat & 3520 & 2285 & 35.09 & 1500 & 57.39 \\
\hline
\end{tabular}

The value of TSS and TDS found from the sample has crossed permissible limit as the tolerable limit is $2000 \mathrm{mg} / \mathrm{L}$ for total dissolved solid and $200 \mathrm{mg} / \mathrm{L}$ for total suspended solid and the sample possesses value exceeding the tolerable limit. So, the value found by experiment shows that the water possesses TS, TDS and

Table 8: Values of Total Suspended Solid (TS) of municipal wastewater.

\begin{tabular}{|c|c|c|c|c|c|}
\hline Location & Initial TSS (mg/l) & $\mathbf{1}^{\text {st }}$ Trial TSS (mg/l) & Removal (\%) & 2 $^{\text {nd }}$ Trial TSS(mg/l) & Removal (\%) \\
\hline City Hat & 400 & 270 & 32.5 & 196 & 51 \\
\hline
\end{tabular}

\section{Determination of organic content}

The maximum allowable limit of total organic content is $200 \mathrm{mg} / \mathrm{L}$. The value of total organic content found from the sample is within permissible limit as the tolerable limit is $200 \mathrm{mg} / \mathrm{L}$ and the sample possesses total organic content value within the tolerable limit. So, the value found by experiment shows that the water possesses organic content that is permissible, and it has very less effect in pollution of wastewater (Table 9).

Table 9: Total organic content values of municipal wastewater of Rajshahi City.

\begin{tabular}{|c|c|c|c|}
\hline Location & $\begin{array}{c}\text { Initial OC } \\
\text { (mg/L) }\end{array}$ & $\begin{array}{c}\mathbf{1}^{\text {st }} \text { trial OC } \\
(\mathbf{m g} / \mathbf{L})\end{array}$ & $\begin{array}{c}\mathbf{2}^{\text {nd }} \text { trial } \mathbf{~ O C} \\
(\mathbf{m g} / \mathbf{L})\end{array}$ \\
\hline City Hat & 109 & 96 & 88 \\
\hline
\end{tabular}

\section{Conclusion}

From this study, the following conclusions can be drawn from the experimental results:

1. Water of Rajshahi City is highly turbid. But after treatment, it is below the permeable limit and turbidity is removed at a successful rate. Up to $90 \%$ turbidity of the wastewater has been removed.
TSS that is not permissible, and it has very significant effect in pollution of wastewater. It exceeded maximum permissible limit for both direct discharge into natural water bodies and for use in irrigation (Table 8).
2. Total solid, total suspended solid and total dissolved solid of the wastewater have be removed up to more than $50 \%$. After all, all values are within the permeable limits.

3. All other parameters are under permeable limit and don't bear any harmful effect.

\section{Recommendation}

Based on the research, following recommendations are given for further study in future:

1. The turbidity of the wastewater of Rajshahi City was high and above the maximum permissible limit. In this study it has been tried to reduce the turbidity at a high range. Up to $90 \%$ turbidity has been removed. There is a scope to reduce its value up to $99 \%$. If proper steps and change the filter media of the filter unit, it may be possible to do this.

2. In this study a short range of total solid, total suspended solid and total dissolved solid has been removed. These values are just below their maximum permissible limit. These values may be increased up to $95 \%$. This is a great scope to do this in this experiment. 
3. In this study maximum number of layers of filter media is four layers and the lengths of these layers are not long. So, there is a great scope to use more than four layers and increasing their lengths which will increase the performance of the filter unit.

\section{References}

1. (2012) Water and Sanitation Program: FY12 end of year report. Sanitation-Program-FY12-end-of-year-report WSP.

2. Howard S Peavy, Donald R Rowe, George Tchobanoglous (1985) Environmental Engineering. McGraw-Hill series in water resources and environmental engineering, New York, McGraw-Hill, USA.

3. Nelson J, Bishay F, Van Roodselaar A, Ikonomou M, Law FC (2007) The use of in vitro bioassays to quantify endocrine disrupting chemicals in municipal wastewater treatment plant effluents. Sci Total Environ 374(1): 80-90.

4. Tilley E, Ulrich L, Luthi C, Reymond Ph, Zurbrugg C (1997) Compendium of Sanitation Systems and Technologies (2 ${ }^{\text {nd }}$ Revised Edition 1997).

5. Water and Sanitation Program (2012) Benchmarking for performance improvement in urban utilities. A review in Bangladesh, India and Pakistan. 16.
6. Swiss Federal Institute of Aquatic Science and Technology (Eawag), Duebendorf, Switzerland, p. 175.

7. Yue Zhang (2012) Design of a Constructed Wetland for Wastewater Treatment and Reuse in Mount Pleasant, Utah. All Graduate Plan B and other Reports, Utah State University, USA, 1: 13-16.

8. World Health Organization (WHO). Filtration of water supplies.

9. Buchan James (2003) Crowded with genius: the Scottish enlightenment: Edinburgh's moment of the mind. BRIEF HISTORY DURING THE SNOW ERA, Harper Collins, New York, USA.

10. HDR Engineering (2001) Handbook of Public Water Systems. John Wiley and Sons, New York, USA, p. 353.

11. Concepts and Practice of Humanitarian Medicine. An Act to make better Provision respecting the Supply of Water to the Metropolis, (15 and 16 Vic. C.84)

12. Johnson George (March 1914) "Present Day Water Filtration Practice". American Water Works Association 1(1): 31.

13. History Poughkeepsies' Water Treatment Facility. Poughkeepsies' Water Treatment Facility.

14. Rangwala SC, Rangwala KS, Rangwala PS (2000) Water supply and sanitary engineering ( $17^{\text {th }}$ edn $)$, p. 199.

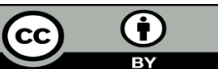

This work is licensed under Creative Commons Attribution 4.0 License

To Submit Your Article Click Here:

Submit Article

DOI: $10.32474 /$ TCEIA.2019.03.000163

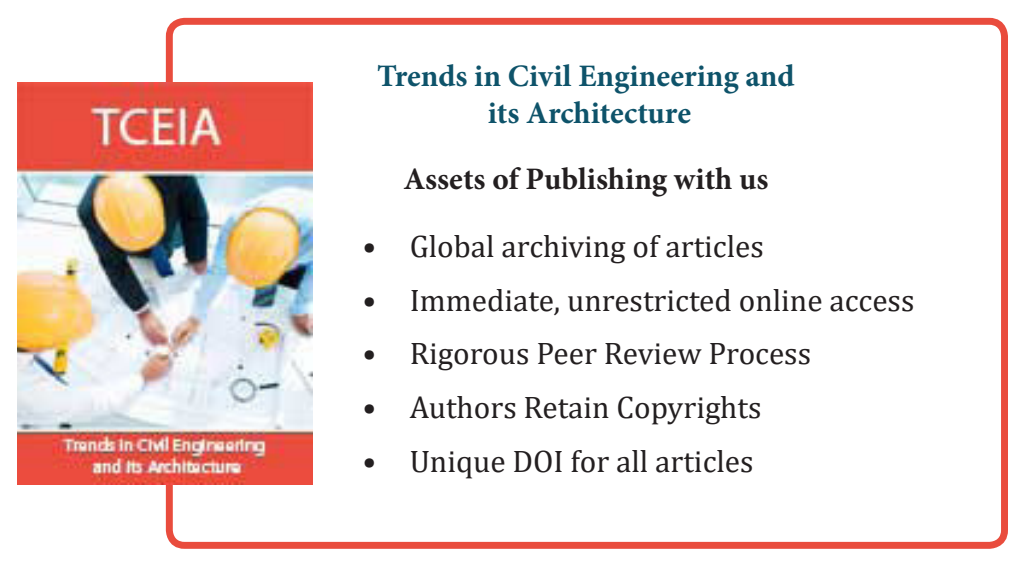

